\title{
HUBUNGAN STATUS ANEMIA, PRAKTIK PEMBERIAN MAKAN, PRAKTIK PERAWATAN KESEHATAN, DAN STIMULASI KOGNITIF DENGAN FUNGSI KOGNITIF ANAK SEKOLAH DASAR
}

\author{
Desty Ervira Puspaningtyas ${ }^{1}$, Toto Sudargo ${ }^{1}$, Nurul Huda Syamsiatun ${ }^{2}$ \\ 1Jurusan Gizi, Fakultas Kedokteran, Universitas Gadjah Mada, Yogyakarta \\ 2 Jurusan Gizi, Politeknik Kesehatan Kemenkes Yogyakarta \\ desty_ep@yahoo.co.id
}

\begin{abstract}
ABSTRAK
Tujuan dari penelitian ini adalah mengetahui hubungan antara status anemia, praktek pemberian makan pada anak, pemeliharaan kesehatan anak, dan stimulasi kognitif pada fungsi kognitif anak sekolah dasar umur 9-13 tahun yang tinggal di Kabupaten Imogiri kota Bantul, Yogjakarta, Sebanyak 120 anak terplih secara acak sederhana, tetapi 7 diantaranya tidak mengikuti test kognitif. Status anemia ditentukan berdasarkan konsentrasi kadar hemoglobin secara cyanmethemoglobin. Data tentang kebiasaan pemberian makan anak, praktik pemeliharaan kesehatan dan stimulasi kognitif anak diambil dengan pertanyaan yang diajukan pada orang ibunya melalui kuesioner. Fungsi kognitif diukur dengan metoda CFIT dan hasil belajar di sekolahnya, termasuk pada mata ajaran Bahasa Indonesia dan maematika. Uji Hubungan 2 variabel menunjukkan bahwa terdapat hubungan yang bermakna antara status anemia dengan angka matematika ( $p=0.005, \rho$ spearman 0.264$)$, praktek pemberian makan pada anak dengan angka matematika $(p=0.029$, $\rho$ spearman 0.206$)$, dan stimulasi kognitif dengan angka matematika $(p=0.027$, $\rho$ spearman 0.208 ). Dapat disimpulkan bahwa dalam penelitian ini status anemia, praktik pemberian makanan anak dan stimulasi kogntif pada anak mempunyai hubungan yang bermakna terhadap fungsi kognitif anak, terutama pada angka pencapaian matematika.
\end{abstract}

Kata kunci: status anemia, praktik pemberian makan pada anak, stimulasi kognitif, fungsi kognitif, anak sekolah dasar

\section{THE RELATIONSHIP BETWEEN ANEMIA STATUS, FEEDING PRACTICES, HEALTH CARE PRACTICES, AND COGNITIVE STIMULATION TO COGNITIVE FUNCTION OF ELEMENTARY SCHOOL CHILDREN}

\section{ABSTRACT}

The aim of this study was to examine correlation between anemia status, feeding practices, health care practices, and cognitive stimulation with cognitive function of school aged children aged 9-13 years. One hundred and twenty children lived in Imogiri district of Bantul in DIY province were chosen using simple random sampling method. Seven subjects did not follow cognitive test. Anemia status was taken from hemoglobin concentration using the cyanmethemoglobin method. Data on feeding practices, health care practices, and cognitive stimulation were collected by asking their parents using questionnaire. Cognitive function was measured by CFIT method and school performance, included Indonesian language and mathematics. Bivariate analysis showed significant correlation between anemia status and mathematics score ( $p=0.005, \rho$ spearman 0.264$)$, feeding practices with mathematics score $(p=0.029, \rho$ spearman 0.206$)$, and cognitive stimulation with mathematics score ( $p=0.027, \rho$ spearman 0.208$)$. In conclusion, anemia status, feeding practices, and cognitive stimulation had significant correlations to cognitive function, especially mathematics score.

Keywords: anemia status, feeding practices, cognitive stimulation, cognitive function, school aged children.

\section{PENDAHULUAN}

S ekarang ini kualitas pendidikan di Indonesia masih dianggap rendah dan cenderung memburuk. Hal ini dibuktikan dengan masih rendahnya kemampuan murid tingkat VIII dibandingkan negara tetangga di Asia pada ujian-ujian Internasional di tahun 2001. ${ }^{1}$ Bukti lain menunjukkan bahwa pada awal tahun 1990, tingkat melek huruf anak Indonesia masih rendah. Anak-anak Indonesia hanya mendapatkan angka 52, di bawah Hong 
Kong (76), Singapura (74), Thailand (65), dan Filipina (53) pada uji kemampuan membaca yang diadakan oleh Asosiasi Pendidikan Internasional. Bahkan, sampai tahun 2002 tingkat melek huruf laki-laki hanya mencapai 87 persen sementara tingkat melek huruf perempuan hanya sebesar 76 persen. ${ }^{2}$

Pendidikan yang tepat akan menghasilkan kualitas SDM dengan pengetahuan dan keahlian yang kompetitif yang senantiasa terkait dengan fungsi kognitif. Akhir-akhir ini kegiatan kognitif dipelajari sebagai suatu aktivitas mengolah informasi yang terbagi dalam beberapa tahap kegiatan. $3,4,5$

Salah satu hambatan dalam mengolah informasi adalah anemia. Prevalensi anemia pada anak sekolah dasar (SD) di dunia mencapai 33 persen. ${ }^{6}$ Prevalensi anemia di kalangan siswa SD pada 200 sekolah di Indonesia tahun 2007-2008 mencapai 20-30 persen. ${ }^{7}$ Sementara itu, prevalensi anemia pada anak SD di Kecamatan Imogiri, Kabupaten Bantul, Provinsi DIY sebesar 78,3 persen. ${ }^{8}$

Anemia selama masa anak-anak dapat menyebabkan penurunan konsentrasi belajar dan fungsi kognitif., 9,10,11 Sebaliknya, anak dengan kadar $\mathrm{Hb}$ yang baik (non-anemia) memiliki kemampuan belajar yang tinggi, yakni setiap kenaikan $\mathrm{Hb}$ sebesar $1 \mathrm{~g} / \mathrm{dL}$, prestasi belajar akan meningkat 2,3 kali.12 Bahkan, IQ total pada anak anemia 12,9 poin lebih rendah dari anak normal. ${ }^{13}$

Selain kejadian anemia, terdapat faktor lain yang turut mempengaruhi kognitif, yaitu faktor genetik ${ }^{3}$, pola asuh, lama pendidikan orang tua, kondisi ekonomi keluarga, hubungan dalam keluarga, tipe keluarga, lingkungan rumah ${ }^{14}$, praktik pemberian makan, praktik perawatan kesehatan ${ }^{15,16}$, dan stimulasi kognitif. ${ }^{17,18}$

Keluarga adalah lingkungan pertama yang berpengaruh terhadap tumbuh kembang anak, termasuk tumbuh kembang kognitif. ${ }^{14}$ Pengaruh keluarga dapat dilihat dari praktik pemberian makan, praktik perawatan kesehatan, dan stimulasi kognitif terhadap anak. Beberapa studi menunjukkan praktik pemberian makan dan praktik perawatan kesehatan berhubungan dengan tumbuh-kembang anak, termasuk perkembangan kognitif. ${ }^{15,16,19}$ Namun, selama ini praktik tersebut belum dipraktikkan secara menyeluruh. Peningkatan kejadian kurang gizi di Indonesia pada tahun 2002 (27\%) dari tahun $2000(25 \%)$ berkaitan dengan praktik pemberian makan. Bukti lain adalah masih rendahnya akses air bersih $(50 \%)$ dan sanitasi $(60 \%)$, serta tingginya tingkat pencemaran air oleh tinja $(80 \%)$ di Indonesia pada tahun $2004 .{ }^{2}$ Selain praktik pemberian makan dan praktik perawatan kesehatan, stimulasi sangat berpengaruh pada kognitif anak. ${ }^{20}$ Stimulasi terhadap anak dapat meningkatkan kemampuan kognitif anak, khususnya kemampuan IQ (Intelligence Quotient) total, IQ verbal, IQ performansi, PPVT (Peabody Picture Vocabulary), analisis verbal, dan membaca. ${ }^{18}$

Permasalahan yang terjadi adalah semakin rendahnya kualitas pendidikan di Indonesia, masih merebaknya kejadian anemia pada anak $S D$, besarnya dampak anemia terhadap kognitif, penelitian mengenai praktik pemberian makan dan praktik perawatan kesehatan terkait kognitif, serta stimulasi kognitif terkait kognitif masih jarang dilaporkan. Hal ini menjadi dasar peneliti untuk mengkaji hubungan antara status anemia, praktik pemberian makan, praktik perawatan kesehatan, dan stimulasi kognitif dengan fungsi kognitif anak SD. Dengan demikian, hasil penelitian ini dapat menjadi masukan penanggulangan permasalahan pendidikan dan kualitas SDM (Sumber Daya Manusia), khususnya penanggulangan berdasarkan sudut pandang gizi.

\section{METODE PENELITIAN}

Jenis penelitian ini adalah observasional dengan rancangan cross-sectional. Penelitian ini dilaksanakan di kecamatan Imogiri, kabupaten Bantul, provinsi DIY pada bulan Oktober tahun 2009 sampai dengan bulan Januari tahun 2010.

Alasan pemilihan Kecamatan Imogiri, Kabupaten Bantul, Provinsi DIY sebagai lokasi penelitian adalah tingginya prevalensi anemia pada anak SD di daerah Imogiri, yakni sebesar 78,3 persen $^{8}$, masih rendahnya cakupan PHBS $(58,13 \%)$ dan posyandu aktif $(33,64 \%)$ di daerah Imogiri21, dan kemudahan administratif serta keterjangkauan wilayah.

Populasi penelitian adalah semua anak SD usia 9-13 tahun yang berdomisili di kecamatan Imogiri, kabupaten Bantul, provinsi DIY. Subjek penelitian ini adalah siswa SD yang memenuhi kriteria yang ditetapkan. Kriteria inklusi adalah anak sekolah dasar yang berusia 9-13 tahun, 
bersedia berpartisipasi dalam penelitian baik yang di rumah maupun di sekolah, dan sudah tinggal di lokasi penelitian minimal selama 6 bulan. Kriteria eksklusi adalah pada anak perempuan yang sudah menstruasi, tidak mengikuti tes fungsi kognitif.

Subjek penelitian diambil dari dua sekolah dasar (SD) yang berbeda, yaitu SDN Sriharjo dan SDN Ngrancah. Alasan pemilihan SD ini adalah jumlah anak SD di daerah tersebut, keterjangkauan wilayah, dan kemudahan administratif. SD ini merupakan SD dengan jumlah anak didik terbanyak dan masih mudah dijangkau oleh kendaraan bermotor. Semakin tinggi wilayah semakin sedikit jumlah anak didik dan semakin sulit dijangkau oleh kendaraan bermotor.

Di sekolah terpilih dilakukan pemilihan subjek secara acak sederhana berdasarkan rumus untuk penelitian cross-sectiona/22 dengan tingkat kemaknaan 0,05 ; proporsi anemia 78,3 persen; dan jumlah beda yang diharapkan sebesar 7 persen. Dari jumlah anak SD 1171 orang, terhitung 119,96 dan dibulatkan menjadi 120 orang. Selama penelitian tujuh subjek tidak mengikuti tes fungsi kognitif karena sakit sehingga jumlah subjek yang diuji secara statistik sebanyak 113 subjek.

Variabel terikat dalam penelitian ini adalah fungsi kognitif, meliputi kemampuan nonverbal/skor CFIT (Culture Fair Intelligence Test) dan prestasi belajar (nilai bahasa Indonesia dan nilai matematika). Variabel terikat dalam penelitian diukur secara interval dan rasio. Untuk kepentingan penyajian data, variabel terikat akan ditampilkan secara kategorikal. Kategori skor CFIT adalah di atas rata-rata (skor CFIT $\geq 90$ ) dan di bawah rata-rata (skor CFIT < 90). Nilai bahasa Indonesia dan nilai matematika dikategorikan dengan rerata hipotetik, yaitu baik (nilai $\geq 66,67$ ) dan kurang baik (nilai <66,67).

Variabel bebas terdiri dari status anemia, praktik pemberian makan, praktik perawatan kesehatan, dan stimulasi kognitif. Variabel bebas dalam penelitian ini diukur secara rasio. Untuk kepentingan penyajian data, variabel bebas akan ditampilkan secara kategorikal. Kategori status anemia adalah anemia (kadar $\mathrm{Hb}<12 \mathrm{~g} / \mathrm{dL}$ ) dan tidak anemia (kadar $\mathrm{Hb} \geq 12$ $\mathrm{g} / \mathrm{dL}$ ). Praktik pemberian makan dan praktik perawatan kesehatan dikategorikan dengan rerata hipotetik, yaitu baik (skor $\geq 17,33$ ); sedang $(8,67 \leq$ skor < 17,33); kurang (skor < 8,67). Stimulasi kognitif dikatagorikan dengan rerata hipotetik, yaitu baik (skor $\geq 74$ ); sedang $(37 \leq$ skor $<74)$; kurang (skor $<3 \overline{7})$.

Data primer diperoleh melalui wawancara langsung terhadap orang tua subjek dengan menggunakan kuesioner; data kadar $\mathrm{Hb}$ diperoleh melalui pemeriksaan darah dengan metode cyamethemoglobin; data kemampuan non-verbal diperoleh dengan melakukan uji intelegensi oleh lembaga psikologi; data praktik pemberian makan, praktik perawatan kesehatan, dan stimulasi kognitif diperoleh melalui wawancara langsung terhadap orang tua subjek menggunakan kuesioner. Wawancara dilakukan oleh mahasiswa program S1 Gizi Kesehatan UGM. Sementara itu data sekunder dikumpulkan melalui dokumen sekolah, meliputi data alamat, nomor telepon, dan prestasi belajar subjek. Data prestasi belajar yang dipakai adalah hasil ujian akhir semester siswa.

Analisis data dilakukan secara univariat dan bivariat. Uji korelasi dilakukan untuk melihat hubungan antara status anemia, praktik pemberian makan, praktik perawatan kesehatan, dan stimulasi kognitif dengan fungsi kognitif.

\section{HASIL}

\section{Karakteristik Subjek Penelitian}

Perbandingan subjek laki-laki dan perempuan yang digunakan dalam penelitian adalah 1:1 dengan usia rata-rata subjek adalah 9.88 tahun. Empat per lima dari subjek penelitian merupakan subjek dengan jumlah anak dalam satu keluarga kurang dari 3, lahir dengan berat badan lebih dari $2,5 \mathrm{~kg}$, dan memiliki status gizi normal. Seluruh subjek penelitian lahir cukup bulan. Sebagian besar pendidikan yang dimiliki ayah dan ibu subjek penelitian adalah pendidikan dasar. Sebagian besar pekerjaan yang dimiliki ayah dan ibu subjek penelitian adalah buruh atau petani. Lebih dari separuh orang tua subjek penelitian memiliki pendapatan lebih rendah dari UMR (Upah Minimum Regional). Sebagian besar subjek penelitian tinggal dalam keluarga inti. Selain itu, diketahui pula bahwa pendidikan ibu memiliki hubungan yang signifikan dengan kemampuan non-verbal 
anak. Status pendapatan memiliki hubungan yang signifikan dengan prestasi belajar matematika anak.

\section{Hubungan antara Status Anemia dengan Fungsi Kognitif Anak Sekolah Dasar}

Anak yang tidak menderita anemia memiliki rerata kemampuan non-verbal, nilai bahasa
Indonesia, dan nilai matematika lebih tinggi dibanding anak yang menderita anemia. Anemia tampak berpengaruh terhadap nilai matematika $(\rho=0.264)$, tetapi tidak berpengaruh terhadap kemampuan non-verbal dan nilai bahasa Indonesia (Tabel 1).

Tabel 1

Skor Fungsi Kognitif Menurut Status Anemia

\begin{tabular}{lcccccccccc}
\hline \multirow{2}{*}{ Status Anemia } & \multicolumn{2}{c}{$\begin{array}{c}\text { Kemampuan Non-Verbal } \\
\text { (skor CFIT) }\end{array}$} & \multicolumn{3}{c}{$\begin{array}{c}\text { Prestasi Belajar } \\
\text { (Nilai Bahasa Indonesia) }\end{array}$} & \multicolumn{3}{c}{$\begin{array}{c}\text { Prestasi Belajar } \\
\text { (Nilai Matematika) }\end{array}$} \\
\cline { 2 - 12 } & Mean & SD & $p$ & Mean & SD & $p$ & Mean & SD & $p$ \\
\hline Tidak Anemia & 94,52 & 14,267 & 0,185 & 72,54 & 12,999 & 0,142 & $60.00^{*}$ & $30-94^{* *}$ & 0,264 \\
Anemia & 89,96 & 14,294 & 0,05 & 70,87 & 11,242 & 0,134 & 56.87 & 13.729 & $0,005^{\circ}$ \\
\hline *
\end{tabular}

๑ signifikan pada $p<0.05$ (Uji Spearman)

Hubungan Antara Praktik Pemberian Makan dengan Fungsi Kognitif Anak Sekolah Dasar

Anak dengan praktik pemberian makan baik memiliki rerata kemampuan non-verbal dan nilai matematika lebih tinggi dibanding anak dengan praktik pemberian makan sedang dan kurang, tetapi tidak untuk bahasa Indonesia. Praktik pemberian makan berpengaruh terhadap nilai matematika $(\rho=0.206)$, tetapi tidak berpengaruh terhadap kemampuan non-verbal dan nilai bahasa Indonesia (Tabel 2).

Tabel 2

Skor Fungsi Kognitif menurut Praktik Pemberian Makan

\begin{tabular}{lccccccccc}
\hline $\begin{array}{l}\text { Praktik } \\
\text { Pemberian } \\
\text { Makan }\end{array}$ & \multicolumn{2}{c}{$\begin{array}{c}\text { Kemampuan Non-Verbal } \\
\text { (skor CFIT) }\end{array}$} & \multicolumn{2}{c}{$\begin{array}{c}\text { Prestasi Belajar } \\
\text { (Nilai Bahasa Indonesia) }\end{array}$} & \multicolumn{2}{c}{$\begin{array}{c}\text { Prestasi Belajar } \\
\text { (Nilai Matematika) }\end{array}$} \\
\cline { 2 - 11 } & Mean & SD & $\rho$ & Mean & SD & $\rho$ & Mean & SD & $\rho$ \\
\hline Baik & 96,48 & 12,271 & 0,168 & 73,97 & 10,048 & 0,005 & 61,58 & 13,741 & 0.206 \\
Sedang & $94^{*}$ & $64-125^{* *}$ & 0,076 & 70,29 & 13,486 & 0,956 & $60^{*}$ & $(30-94)^{* *}$ & $0.029 \odot$ \\
Kurang & 89 & 16,525 & & 78,17 & 12,342 & & 52,92 & 13,028 & \\
\hline
\end{tabular}

${ }^{*}$ Median $\quad{ }^{* *}$ Minimum - Maksimum

$\odot$ signifikan pada $p<.05$ (Uji Spearman)

\section{Hubungan Antara Praktik Perawatan Kesehatan dengan Fungsi Kognitif Anak Sekolah Dasar}

Anak dengan praktik perawatan kesehatan baik dan sedang memiliki rerata kemampuan non-verbal dan nilai matematika lebih tinggi dibanding anak dengan perawatan kesehatan kurang. Anak dengan praktik perawatan kesehatan baik memiliki nilai Bahasa Indonesia tidak jauh berbeda dibanding anak dengan praktik perawatan kesehatan sedang dan kurang. Tidak terdapat korelasi antara praktik perawatan kesehatan dengan fungsi kognitif, baik kemampuan non-verbal maupun prestasi belajar (nilai Bahasa Indonesia dan nilai matematika) (Tabel 3). 
Tabel 3

Skor Fungsi Kognitif menurut Praktik Perawatan Kesehatan

\begin{tabular}{lccccccccc}
\hline $\begin{array}{l}\text { Praktik } \\
\text { Perawatan }\end{array}$ & \multicolumn{2}{c}{$\begin{array}{c}\text { Kemampuan Non-Verbal } \\
\text { (skor CFIT) }\end{array}$} & \multicolumn{3}{c}{$\begin{array}{c}\text { Prestasi Belajar } \\
\text { (Nilai Bahasa Indonesia) }\end{array}$} & \multicolumn{3}{c}{$\begin{array}{c}\text { Prestasi Belajar } \\
\text { (Nilai Matematika) }\end{array}$} \\
\cline { 2 - 11 } Kesehatan & Mean & SD & $p$ & Mean & SD & p & Mean & SD & $p$ \\
\hline Baik & 93,65 & 14,230 & 0,174 & 72,24 & 12,112 & 0,079 & $60^{*}$ & $(30-90)^{* *}$ & 0,085 \\
Sedang & 94,95 & 14,786 & 0,065 & 72 & 15,513 & 0,405 & $60^{*}$ & $(40-94)^{* *}$ & 0,370 \\
Kurang & $76^{*}$ & $(73-97)^{* *}$ & & $72^{*}$ & $(68-78)^{* *}$ & & $43^{*}$ & $(35-61)^{* *}$ & \\
\hline${ }^{*}$ Median & \multicolumn{4}{c}{${ }^{* *}$ Minimum - Maksimum } & & & & &
\end{tabular}

\section{Hubungan Antara Stimulasi Kognitif dengan Fungsi Kognitif Anak Sekolah Dasar}

Anak dengan stimulasi kognitif baik memiliki rerata kemampuan non-verbal dan nilai bahasa Indonesia lebih tinggi dibanding anak dengan stimulasi kognitif sedang dan kurang.
Anak dengan stimulasi kognitif baik dan sedang memiliki rerata nilai matematika lebih tinggi dibanding anak dengan stimulasi kognitif kurang. Stimulasi kognitif berpengaruh terhadap nilai matematika $(\rho=0,208)$, tetapi tidak berpengaruh terhadap kemampuan non-verbal dan nilai bahasa Indonesia (Tabel 4).

Tabel 4

Skor Fungsi Kognitif menurut Stimulasi Kognitif

\begin{tabular}{lcccccccccc}
\hline \multirow{2}{*}{$\begin{array}{l}\text { Stimulasi } \\
\text { Kognitif }\end{array}$} & \multicolumn{2}{c}{$\begin{array}{c}\text { Kemampuan Non-Verbal } \\
\text { (skor CFIT) }\end{array}$} & \multicolumn{3}{c}{$\begin{array}{c}\text { Prestasi Belajar } \\
\text { (Nilai Bahasa Indonesia) }\end{array}$} & \multicolumn{3}{c}{$\begin{array}{c}\text { Prestasi Belajar } \\
\text { (Nilai Matematika) }\end{array}$} \\
\cline { 2 - 12 } & Mean & SD & $p$ & Mean & SD & $p$ & Mean & SD & $p$ \\
\hline Baik & 95,50 & 17,180 & 0,174 & 75,38 & 10,609 & 0,089 & 57,50 & 14,813 & 0,208 \\
Sedang & 95,15 & 13,592 & 0,066 & 72,69 & 12,974 & 0,348 & $60^{*}$ & $(30-94)^{* *}$ & $0,027^{\circ}$ \\
Kurang & 89,73 & 14,909 & & 70,36 & 12,402 & & 53,27 & 13,545 & \\
\hline
\end{tabular}

${ }^{*}$ Median ${ }^{* *}$ Minimum - Maksimum

${ }^{\odot}$ signifikan pada $p<.05$ (Uji Spearman)

\section{BAHASAN}

\section{Hubungan Antara Status Anemia dengan Fungsi Kognitif Anak Sekolah Dasar}

Status anemia memiliki hubungan bermakna dengan fungsi kognitif, dalam hal ini prestasi belajar matematika. Semakin tinggi kadar $\mathrm{Hb}$, semakin tinggi pula nilai matematika. Namun demikian, hubungan tersebut lemah.

Penelitian Sunthong, et al. (2002), mengungkapkan nilai matematika memiliki hubungan yang signifikan dengan kadar $\mathrm{Hb}$ dan kadar feritin anak sekolah. Nilai matematika anak akan meningkat dengan meningkatnya kadar $\mathrm{Hb}_{2}{ }^{23}$ Anak non-anemia memiliki kemampuan belajar yang tinggi, yakni setiap kenaikan $\mathrm{Hb}$ sebesar $1 \mathrm{~g} / \mathrm{dL}$, prestasi belajar anak akan meningkat 2,3 kali.

Anemia menyebabkan rendahnya kemampuan mental, IQ, dan performa skolastik pada anak sekolah. Selain itu, kemampuan aritmatika anak juga cenderung rendah dengan semakin parahnya tingkat anemia. Anak dengan defisiensi besi akan mengalami penurunan tingkat kecerdasan 5-10 IQ poin. ${ }^{12} \mathrm{Hal}$ ini disebabkan karena perhatian dan tingkat konsentrasi pada anak anemia cenderung rendah. ${ }^{24}$ 
Adapun senyawa yang berperan terhadap kemampuan kognitif anak adalah hemoglobin. Besi merupakan salah satu komponen penyusun hemoglobin. Nilai matematika pada anak sekolah cenderung rendah karena adanya defisiensi besi, baik disertai anemia maupun tidak anemia. Anak dengan defisiensi besi berisiko 2,3 kali memiliki nilai matematika yang rendah dibanding anak dengan status besi tubuh normal. ${ }^{25}$

Defisiensi besi dapat menyebabkan abnormalitas pada tiga domain otak, yaitu penurunan struktur dendritik, peningkatan glutamat serta GABA ( $y$-aminobutiric acid) pada hipokampus, hipomielinasi syaraf, dan perubahan metabolisme neurotransmitter dopamin. $26-31$

Defisiensi besi akan mengurangi kadar sitokrom $\mathrm{C}$ di otak, yang berfungsi sebagai tempat penghasil energi di syaraf, khususnya di hipokampus dan korteks frontal. Selain berpengaruh terhadap perkembangan hipokampus dan korteks frontal, besi juga berpengaruh terhadap perkembangan striatum. ${ }^{28}$

Hipokampus merupakan bagian otak yang berperan dalam pengaturan penyimpanan memori31,32. Hipokampus merupakan bagian otak yang berperan dalam ingatan spasial dan kondisional ${ }^{33}$. Korteks frontal adalah bagian otak yang berpengaruh terhadap daya berfikir abstrak dan sebab akibat ${ }^{32}$. Striatum adalah bagian dari basal ganglia. Hubungan antarstriatal berpengaruh terhadap fungsi kognitif, proses emosional, dan tingkat motivasi. ${ }^{31}$ Striatum diduga menyimpan ingatan untuk hubungan yang konsisten antara stimulus dan respon. Tipe ingatan pada striatum berkembang secara inkremental (sedikit demi sedikit). ${ }^{34}$ Apabila bagian otak $\mathrm{di}$ atas mengalami gangguan, maka proses berfikir dan belajar akan terganggu.

\section{Hubungan Antara Praktik Pemberian Makan dengan Fungsi Kognitif Anak Sekolah Dasar}

Praktik pemberian makan memiliki hubungan yang bermakna dengan fungsi kognitif, dalam hal ini prestasi belajar matematika. Praktik pemberian makan berhubungan positif dengan nilai matematika. Semakin baik praktik pemberian makan anak, semakin baik pula nilai matematika anak.
Namun demikian, hubungan praktik pemberian makan dengan nilai matematika lemah.

Praktik pemberian makan berhubungan dengan perkembangan emosional, kognitif, dan fisik anak. Menurut UNICEF, makanan dan kesehatan merupakan hal penting dalam pertahanan, pertumbuhan, dan perkembangan anak. Praktik pemberian makan dapat berpengaruh terhadap perkembangan kognitif anak, baik memori, cara memecahkan masalah, pemahaman numerik (matematika), perkembangan bahasa, dan lain-lain. ${ }^{19}$

Praktik pemberian makan berpengaruh terhadap asupan zat gizi dan perkembangan psikososial dan emosional anak. ${ }^{35}$ Pada penelitian ini, praktik pemberian makan anak SD ditinjau dari cara ibu memperhatikan kebiasaan makan anak, menciptakan nafsu makan/membujuk anak makan, memperhatikan keamanan makanan, menciptakan situasi nyaman, memahami waktu makan anak, memantau berat badan anak, dan mengetahui porsi makan anak.

Praktik pemberian makan anak akan berdampak terhadap asupan zat gizi dan pola makan anak. Secara nyata, praktik pemberian makan pada anak memiliki dampak yang penting untuk perkembangan pola makan anak, khususnya keanekaragaman makanan. ${ }^{36}$ Semakin banyak ragam makanan yang dimakan, semakin bervariasi zat gizi yang masuk tubuh sehingga kebutuhan gizi dapat tercukupi ${ }^{37}$, baik kebutuhan akan energi, protein, asam lemak, zinc, tembaga, iodium, vitamin $B_{12}$, maupun zat gizi lain yang penting bagi perkembangan kognitif. Berdasarkan hasil wawancara, diketahui bahwa sebagian besar makanan subjek penelitian cukup beragam, khususnya untuk buah, sayur, dan makanan sumber protein.

Defisiensi zat gizi karena praktik pemberian makan yang kurang baik dalam jangka waktu yang lama dapat mengakibatkan kerusakan pada hipokampus, korteks otak, serebelum, lobus frontalis, dan lobus temporalis. Selain itu, defisiensi zat gizi dapat mengakibatkan kerusakan amigdala. ${ }^{38}$ Hipokampus berperan dalam reaksi emosional, penentuan keputusan, dan penyimpanan memori, khususnya memori jangka panjang. ${ }^{32,38}$ Cerebellum berfungsi sebagai pemberi respon motorik. Lobus frontalis dan lobus temporalis berfungsi sebagai tempat masuknya informasi. ${ }^{32,33}$ Amigdala berfungsi 
dalam pengaturan proses informasi. ${ }^{32}$ Apabila bagian otak di atas mengalami gangguan, maka proses berfikir dan belajar akan terganggu.

Praktik pemberian makan merupakan salah satu cara agar anak dan pengasuh dapat berinteraksi secara intensif sehingga kemampuan verbal dan non-verbal anak dapat berkembang. Praktik pemberian makan tidak hanya baik untuk pertumbuhan dan kesehatan anak, namun juga untuk perkembangan psikososial dan emosional seorang anak. ${ }^{35}$ Kemampuan emosional merupakan keluaran kognitif yang baik pula. ${ }^{39} \mathrm{Hal}$ ini dikarenakan hipokampus sangat rentan terhadap efek-efek kemampuan yang harus dikembangkan karena kemampuan emosional yang baik akan menghasilkan yang diinduksi oleh kegagalan kemampuan emosional (stres). Stres diketahui akan mengurangi percabangan dendritik di hipokampus, mengurangi neurogenesis dewasa di hipokampus, memodifikasi struktur beberapa sinapsis hipokampal, dan mendisrupsi perfoma dalam tugas-tugas yang bergantung hipokampus yang akan berakhir pada kegagalan fungsi kognitif. ${ }^{33}$

\section{Hubungan Antara Praktik Perawatan Kesehatan dengan Fungsi Kognitif Anak Sekolah Dasar}

Praktik perawatan kesehatan tidak memiliki hubungan yang bermakna dengan fungsi kognitif, baik kemampuan non-verbal (skor CFIT), maupun prestasi belajar (nilai Bahasa Indonesia dan matematika). Hal ini dimungkinkan karena adanya faktor lain yang lebih berpengaruh terhadap fungsi kognitif, baik faktor internal maupun faktor eksternal.

Pendidikan ibu memiliki hubungan yang signifikan dengan kemampuan non-verbal anak. Perbedaan tingkat kemampuan non-verbal anak terlihat antara ibu yang berpendidikan menengah dengan tidak sekolah, pendidikan tinggi dengan tidak sekolah, dan pendidikan tinggi dengan pendidikan dasar. Selain itu, diketahui pula bahwa status pendapatan memiliki hubungan yang signifikan dengan prestasi belajar matematika anak.

Anak yang memiliki orang tua dengan pendidikan yang rendah berisiko memiliki fungsi kognitif lebih rendah 3 kali dari anak yang memiliki orang tua dengan level pendidikan tinggi. Sementara itu, anak yang mendapat pengajaran dari ibu berpendidikan tinggi akan memiliki fungsi kognitif yang tinggi pula. $14,40 \mathrm{Hal}$ ini dikarenakan anak dengan ibu yang memiliki waktu pendidikan lebih lama akan menerima lebih banyak stimulasi (yang lebih berkualitas dan bervariasi) di dalam lingkungan keluarganya dibandingkan stimulasi yang diterima oleh anak yang diasuh oleh ibu yang memiliki waktu pendidikan lebih singkat. Selain itu, ibu dengan pendidikan lebih lama lebih dapat mengatur lingkungan dan emosi serta lebih mudah berinteraksi dengan anaknya. ${ }^{41}$

Dalam beberapa penelitian disebutkan bahwa status sosial ekonomi merupakan salah satu faktor yang mempengaruhi fungsi kognitif seseorang. Anak yang hidup dalam sosial ekonomi menengah ke atas memiliki $I Q$ yang lebih tinggi dibanding anak dengan sosial ekonomi bawah. ${ }^{32}$ Menurut Lawlor, et al., kelas sosial ekonomi ayah pada waktu anak dilahirkan merupakan faktor prediksi yang penting bagi fungsi kognitif anak. Anak yang berasal dari kelas sosial ekonomi terendah memiliki rata-rata nilai IQ 14 poin lebih rendah dibanding anak yang berada pada kelas sosial ekonomi tinggi. ${ }^{42}$ Selain itu, kondisi sosial ekonomi anak juga akan berpengaruh terhadap nilai matematika anak. ${ }^{43}$

\section{Hubungan Antara Stimulasi Kognitif dengan Fungsi Kognitif Anak Sekolah Dasar}

Stimulasi kognitif memiliki hubungan yang bermakna dengan fungsi kognitif, dalam hal ini prestasi belajar matematika. Semakin tinggi stimulasi kognitif pada anak, semakin tinggi pula nilai matematika anak. Namun demikian, stimulasi kognitif dengan nilai matematika memiliki hubungan yang lemah.

Penelitian Walker, et al., menyebutkan adanya stimulasi terhadap anak dapat meningkatkan fungsi kognitif anak, khususnya kemampuan IQ total, IQ verbal, IQ performansi, PPVT, analisis verbal, dan kemampuan membaca. Selain itu, anak tanpa stimulasi cenderung mengalami defisit atau kemunduran kemampuan membaca dan matematika, bahkan ada juga yang dikeluarkan dari sekolah. ${ }^{18}$

Stimulasi dini saat anak berusia $<4$ tahun berpengaruh signifikan terhadap perkembangan otak anak. ${ }^{41,44}$ Adanya stimulasi, baik berupa stimulasi verbal dan non-verbal (orang, objek, dan simbol) akan meningkatkan kognitif anak. 
Hal ini dikarenakan dari stimulasi akan terbentuk suatu informasi dan persepsi. ${ }^{41}$

Pengalaman individu (stimulus) harus diberikan guna menstimulasi perkembangan struktur kognitif. Informasi yang diberikan hendaknya sebagian harus telah dikenal dan sebagian merupakan hal yang baru untuk terjadinya asimilasi ${ }^{5}$. Kognitif selalu terkait dengan proses asimilasi dan akomodasi.,3 Apabila informasi tidak dapat diasimilasi, berarti informasi tersebut tidak dapat dimengerti (akomodasi tidak terjadi). Sebaliknya, apabila seluruhnya dapat dimengerti secara tuntas, tidak diperlukan belajar, sebab tidak terjadi akomodasi sehingga perkembangan anak pun akan terhambat. ${ }^{5,45}$

Dalam penelitian ini, stimulasi kognitif memiliki hubungan yang bermakna dengan fungsi kognitif, khususnya prestasi belajar (nilai matematika) dibanding dengan kemampuan non-verbal (skor CFIT) dan prestasi belajar (nilai bahasa Indonesia). Hal ini dimungkinkan karena pada kemampuan non-verbal dan prestasi belajar (bahasa Indonesia), informasi yang diterima tidak dapat diasimilasi atau mungkin dapat dimengerti secara tuntas sehingga proses akomodasi tidak berlangsung. Sedangkan, pada nilai matematika, informasi yang ada merupakan informasi yang telah dikenal anak, namun masih merupakan informasi baru yang memungkinkan terjadinya asimilasi dan akomodasi sehingga kemampuan belajar dan berfikir anak bisa berkembang.

Stimulasi dapat meningkatkan hubungan antarneuron di jaringan otak. $\mathrm{Hal}$ ini dikarenakan dengan adanya stimulasi, jumlah dan distribusi glikoprotein dan gangliosida otak akan meningkat. ${ }^{46}$ Peningkatan senyawa ini dapat meningkatkan fungsi kognitif anak. Glikoprotein merupakan senyawa yang berperan dalam tingkah laku sosial dan ingatan jangka pendek. Gangliosida merupakan senyawa yang berperan terhadap hubungan antarneuron di membran otak dan korteks frontal. ${ }^{46}$ Korteks frontal merupakan bagian otak yang bertanggung jawab terhadap proses berfikir abstrak dan sebab-akibat. ${ }^{32}$ Selain itu, gangliosida berperan dalam penerimaan dan penyaluran informasi dari rangsangan ke otak. ${ }^{46}$

Adapun keterbatasan penelitian ini adalah tidak memperhitungkan efek kecerdasan ibu, tidak memperhitungkan motivasi belajar, dan faktor lain yang dapat meningkatkan motivasi belajar anak, dan penelitian yang dilakukan adalah penelitian cross-sectional.

\section{SIMPULAN DAN SARAN}

\section{Simpulan \\ Anemia, praktik pemberian makan, dan stimulasi kognitif mempunyai kontribusi terhadap fungsi kognitif, khususnya kemampuan matematika.}

\section{Saran}

Bagi masyarakat khususnya para orang tua diharapkan senantiasa memperhatikan status kesehatan (kejadian anemia), praktik pemberian makan, dan stimulasi kognitif terhadap anak agar fungsi kognitif anak dapat berkembang. Untuk Institusi / Pengambil Kebijakan, diharapkan pihak institusi / pengambil kebijakan mampu melakukan suatu tindakan untuk meningkatkan pengetahuan masyarakat mengenai hubungan anemia, praktik pemberian makan, dan stimulasi kognitif dengan fungsi kognitif anak, misal : penyuluhan. Disamping itu diharapkan pihak institusi / pengambil kebijakan lebih menggalakkan (meningkatkan) programprogram yang turut mendukung terjadinya peningkatan status kesehatan, praktik pemberian makan, dan stimulasi kognitif pada anak, misal penjaringan kesehatan di tingkat sekolah dasar, posyandu, PAUD. Bagi Peneliti, disarankan untuk dilakukan penelitian lebih lanjut mengenai variabel-variabel lain yang berpengaruh terhadap fungsi kognitif, meliputi kemampuan kognitif ibu dan motivasi belajar. Selain itu, penyempurnaan kuesioner juga diperlukan, khususnya kuesioner praktik pemberian makan dan praktik perawatan kesehatan agar tingkat reliabilitas kuesioner bisa lebih dari 0.6049 untuk praktik pemberian makan dan lebih dari 0.6077 untuk praktik perawatan kesehatan.

\section{RUJUKAN}

1. World Bank. 2005. Peningkatan Kualitas Pendidikan. Diakses dari httpsiteresources.worldbank.org.pdf pada tanggal 1 Juni 2009 Pukul 14.07 WIB.

2. Republik Indonesia. Laporan Pembangunan Manusia. Jakarta: BPS, BAPPENAS, UNDP, 2004 
3. Santrock, J.W. Psychology Updated Seventh Edition. New York: Mc Graw Hill; 2005.

4. Soewondo, S. Pengaruh Zat Besi Terhadap Kognisi. Disertasi. Jakarta: Perpustakaan Pusat UI, 2009. Diakses dari http://www.digilib.ui.ac.id pada tanggal 13 Februari 2009 pukul 17.25 WIB

5. Walgito, B. Pengantar Psikologi Umum. Yogyakarta : ANDI; 2004.

6. WHO. 2008. Worldwlde prevalence of anaemla 1993-2005, WHO Global Database on Anaemia. Diakses dari http://whalibdoc.who.pdf pada tanggal 1 Juni 2009 pukul 15.15 WIB

7. Pdpersi. 2008. Angka Prevalensi Anemia pada Balita Tertinggi. Diakses dari http://www.pdpersi.co.id pada tanggal 21 Maret 2009 pukul 13.07.2009

8. Ismail, E. Pengaruh Suplementasi $\mathrm{Fe}$ Folat, Zink, dan Vitamin A Terhadap Prestasi Belajar Siswa Stunted Kelas 4-6 SD.Tesis. Yogyakarta: UGM; 2004.

9. Permaesih, D. Pengaruh Olahraga Aerobik dan Pemberian Pil Besi terhadap Status Besi dan Tingkat Kesegaran Jasmani pada Remaja Bogor: Bogor: Pusat Penelitian dan Pengembangan Gizi dan Makanan; 2003.

10. Sari, M., Martin W.B., Saskia de P., Werner J.S., dan Soemilah S. 2001. "Effect of iron-fortified candies on the iron status of children aged 4-6 y in East Jakarta, Indonesia". American Journal of Clinical Nutrition. 2001;73:1034-9

11. Tsuyuoka, R., J. Wendi Bailey, Alzira M. D’Avila Nery Guimaraes, Ricardo Q. Gurgel, Luis E.C. Anemia and intestinal parasitic infections in primary school students in Aracaju, Sergipe, Brazil. Cad. Saúde Pública, Rio de Janeiro. 1999; 15(2):413-421.

12. Sartono, Wiryatun L., dan Toto $S$. Hubungan Konsumsi Makanan dan Kadar Hemoglobin $(\mathrm{Hb})$ dengan Prestasi Belajar Siswa SLTP Kota Palembang. Jurnal Gizi Klinik Indonesia. 2007; 4 (1)19-29

13. Agaoglu, L., Oktay T., Emin U., Yasemin S., dan Dilek D. Effects of Iron Deficiency Anemia on Cognitive Function in Children. Arzneimittel-Forschung (Drug Research) 2007:57(6a):426-430
14. Isaranurug, S., Sutham N., dan Duangporn K. 2005. Factors Influencing Development of Children Aged One to Under Six Years Old. J Med Assoc Thai. 2005; 8 (1)

15. Anwar, H.M. Peranan Gizi dan Pola Asuh dalam Meningkat Kualitas Tumbuh Kembang Anak. Diakses dari http://www.whandi.net/index.php pada tanggal 10 April 2009 pukul 15.15 WIB

16. Menon, P., Marie, R., Mary A., dan Arsene $F$. Childcare, Nutrition, and Health in the Central Plateau of Haiti : The Role of Community and Caregiver Resources. Food and Nutrition Technical Assistance Project (FANTA). Washington DC : Academy for Educational Development; 2003.

17. Grantham-Mc Gregor, Sally M., Susan P.W., Susan M.C., dan Christine A.P. Effect of Early Childhood Supplementation with and without Stimulation on Later Development in Stunted Jamaican Children. American Journal of Clinical Nutrition. 1997;66:247-53

18. Walker, S.P., Susan M.C., Christine A.P., dan Sally M.G. Effect of Early Chilhood Psychosocial Stimulation and Nutritional Supplementation on Cognition and Education in Growth-Stunted Jamaican Children: Prospective Cohort Study. Lancet. 2005;366:1804-07

19. Engle, P. The Role of Caring Practices and Resources for Care in Child Survival, Growth, and Development: South and Southeast Asia. Asian Development Review. 1999; 17 (1,2):pp.132-167

20. Witarsono. Stimulasi dan Kecerdasan Anak. 2009. Diakses dari http://www.sahabatcahaya.net pada tanggal 19 April 2009 Pukul 14.39 WIB

21. Dinas Kesehatan Yogyakarta. Riskesdas 2007. Yogyakarta: Dinas Kesehatan Yogyakarta; 2008.

22. Lemeshow, H.D.W. dan Klar J. Besar Sampel dalam Penelitian Kesehatan. Yogyakarta: Gadjah Mada University Press; 1997.

23. Sungthong, R., Ladda Mo-suwan, dan Virasaksi C. Effect of Haemoglobin and 
Serum Ferritin on Cognitive Function in School Children. Asia Pacific J Clin Nutr. 2002;11(2):177-122

24. Passi, S. J. dan Sheila C. Vir. Functional Consequences of Nutritional Anemia in School Age Children dalam Nutritional Anemias. Ed: Usha Ramakrishnan. London: CRC Press; 2001.

25. Halterman, J.S., Jeffrey M.K., C. Andrew Aligne, Peggy A., dan Peter G.S. 2001. Iron Deficiency and Cognitive Achievement Among School-Aged Children and Adolescents in the United States. PEDIATRICS. 2001; 107 (6), pp. 1381-1386

26. Batra, J. dan Archana Sood. 2005. Iron Deficiency Anaemia: Effect on Cognitive Development in Children : A Review. Journal of Clinical Biochemistry. 2005; 20(2):119-125

27. Georgieff, M.K. Iron in the Brain, Its Role in Development and Injury. American Academy of Pediatrics: NeoReviews. 2006; 7(7): 344

28. Georgieff, M.K. The role of iron in neurodevelopment : fetal iron de.ciency and the developing hippocampus. Biochemical Society Journal. 2008; 36:1267-1271

29. Gropper, S.S., Jack L.S., dan James L.G. Advanced Nutrition and Human Metabolism Fourth Edition. Wadsworth: Thomson Learning Inc; 2005.

30. Lozoff, B. Iron and Learning Potential. Bull. N.Y. Acad. Med.1989; 65 (10)n

31. Lozoff, B. 2007. "Iron Deficiency and Child Development". Food and Nutrition Bulletin, vol.2:no.4:page 560-571, The United Nations University

32. Fogel, A. dan Gail F.Melson. Child Development Individual, Family, and Society. St Paul, New York: West Publishing Company; 1988.

33. Pinel, J.P.J. Biopsikologi. Diterjemahkan oleh Helly. Prajitno Soetjipto dan Sri Mulyantini Soetjipto. Yogyakarta: Pustaka Pelajar; 2009.

34. Passi, S. J. dan Sheila C. Vir. Functional Consequences of Nutritional Anemia in
School Age Children dalam Nutritional Anemias. Editor Usha Ramakrishnan. New York: CRC Press; 2001.

35. Liu, Y.H. dan Martin T.Stein. Feeding Behaviour of Infants and Young Children and Its Impact on Child Psychosocial and Emotional Development. In: Encyclopedia on Early Childhood Development. Montreal: Centre of Excellence for Early Childhood Development; 2005.

36. Patrick, H., Theresa A.N., Sheryl O.H., Miriam M. 2005. The Benefits of Authoritative Feeding Style: Caregiver Feeding Styles and Children's Food Consumption Patterns. Appetite. 2005; 44: 243-249

37. Ortega, R.M., Ana M.R., Pedro A., Ana M L.S., dan M Elena Q. Dietary Intake and Cognitive Function in a Group of Elderly People. Am J Clin Nutr. 199; 66:803-9

38. Wainwright, P.E. Dan John Colombo. Nutrition and the Development of Cognitive Function: Interpretation of Behavioral Studies in Animals and Human Infants. Am J Clin Nutr. 2006;84:961-70

39. Lembaga Bina Anak dan Perkembangan Masyarakat. Keseimbangan IQ dan EQ. 1999. Diakses dari http://www.fedus.org pada tanggal 17 Juli 2009 pukul 16.45 WIB

40. Nanthamongkolchai, S., Chutima N., dan Chokchai. Influence of Parenting Styles on Development of Children Aged Three to Six Years Old. J Med Assoc Thai. 2007; 90 (5):971

41. Andrade, S.A., Darci N.S., Ana C.B., Marcia R.M.P., Naomar A-F, dan Mauricio L.B. Family Environment and Child's Cognitive Development: an Epidemiological Approach". Rev Saude Publica. 2005;39(4)

42. Puspitasari, F.D. Hubungan antara Status Gizi dan Faktor Sosiodemografi dengan Kemampuan Kognitif Anak Sekolah Dasar di Daerah Endemis GAKY. Skripsi. Yogyakarta : FK UGM, 2008.

43. Jefferis, B.J.M.H., Chris P. dan Clycle H. 2002. Birth Weight, Childhood Sosioeconomic Environment, and Cognitive Development in the 1958 British 
Birth Cohort Study. British Medical Journal. 2002;325:305

44. Andarwati, R. Hubungan antara Berat Badan Lahir, ASI Eksklusif, Status Gizi, dan Stimulasi Kognitif dengan Kecerdasan Anak Usia 5 - 6 Tahun di Kecamatan Prambanan Kabupaten Sleman. Tesis. Yogyakarta: Program Pascasarjana UGM; 2006.
45. Hardy, M. dan Steve Heyes. Pengantar Psikologi. Diterjemahkan oleh Soenardji. Jakarta: Erlangga; 1985.

46. Berra, R., D.A. Primi, dan P. Careddu. The Function of Sialoglycoconjugates and Their Modifications With Reference to Nutrition dalam Nutritional Problems in Childhood, Proceding of International Problems in Childhood. Editor Fiorella Balli. Itali: Piccin Medical Books; 1978. 